UCRL- 91304

FREPRINT

UCRL- -91304

DE86 011886

\title{
COMPLEX DEFECTS IN THE OXIDATION OF URANIUM
}

\author{
R. K. Maccirone \\ S. Sankaran \\ S. R. Shatynski \\ C. A. Colmenares
}

This paper was prepared for subnittal to

1985 TMS-AIME Heeting, New York, IYY

Feb. 24-28, 1985

\section{June 10,1986}

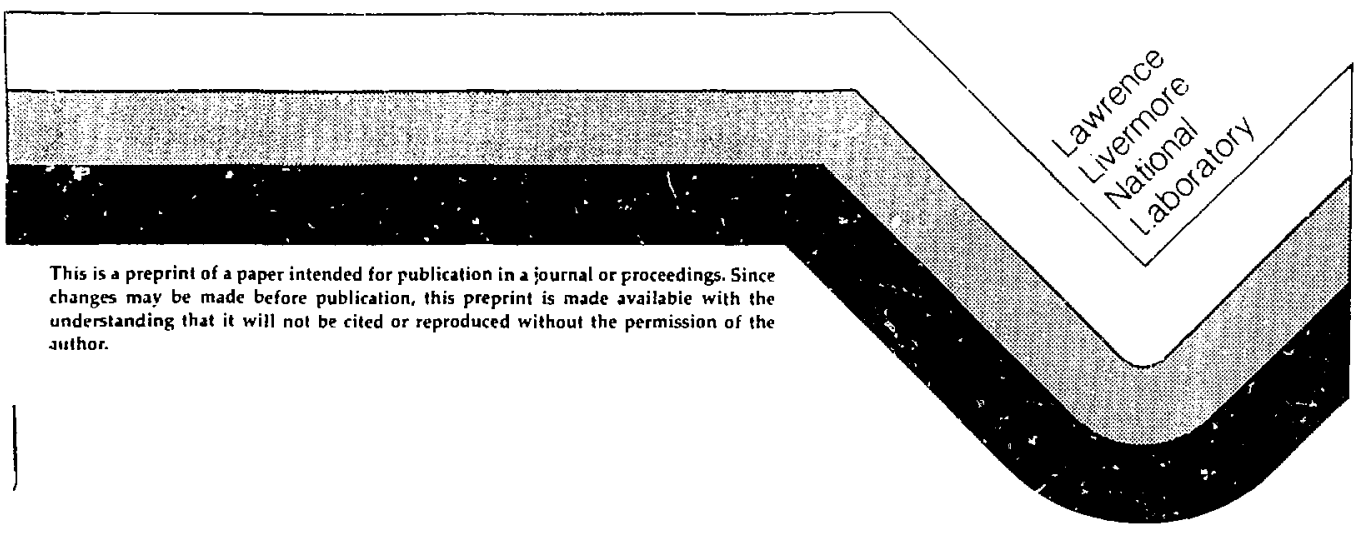


COKPLEX DEFECTS IN THE OXIDATION OF URANIOH

R. K. MacCrone, S. Sankaran and S. R. Shatynsi:i*

Materials Engineering Department

Rensselper Polytechnic Institute

Troy, New York 12181

and

C. A. Colmenares

Lawrence Livermore National Laboratory

Livermore, California 94550

Presented at the 1985 TMS-AIME Meeting,

New York, IJY. Feb. 24-28, 1985.

"Shatynski Memorial Symposium"

To appear in Met. Traces

\section{DISCLAIMER}

This report was prepared as an account of wr,sk sponsored by an agency of the United States Government. Neither the United States Covernmest not any agency thereof, nor any of their employees, makes any warranty, express or implied, or assumes any legal liability or responsibility for the accuricy, completeress, or useluiness of any information, apparatus, product, or *Deceased process disclosed, or represents that its use would not infringe privately owned rights. Reference herein to any specific commercial product, process, or service by trade name, trademark. manufacturer. or otberwise dues not nocessarily constitute or imply its endorsement, recommendation, or favoring by the United States Government or any agency tbereof. The riews and opinions of authors expressed herein to not necessarily state or reflest those of the United States Government or any agency thereof. 


\section{INTRODOCTYON}

The oxidation of uranium in oxygen, water vapor, and oxygen/wacer vapor mixtures has been studied extensively, $1,2,3$ but details of its kinetics and mechanism have not been completely elucidated. Thermogravimetric studies of the reaction pressure defendence 3,4 suggested that oxygen vacancy rich clusters of the type $2\left(v_{0}^{a} O_{i} v_{b}^{b}\right)$ control the oxidation of uranium in air with water vapor in the range of 6 to $17 \mathrm{kPa}$, and oxygen interstitial rlch defects such as $2\left(0_{i}^{a} v_{0} o_{i}^{b}\right)$ in alr with lower water vapor pressures, pure oxygen, and pure water vapor. The extstence of an oxygen interstitial rich complex $2\left(0_{i}^{a} v_{0} a_{i}^{b}\right)$ for $v_{2+x}$ was first proposed by Willis 5 based on his neutron diffraction work $(2: 2: 2$ model). Electrical. conductivity measurements on $\mathrm{UO}_{2+\mathrm{x}}$ and $\mathrm{U}_{4} \mathrm{O}_{9 \pm \mathrm{y}}$ by Matsui and Naito ${ }^{6}$ were interpreted using defect-cluster theory; a 2:2:2 incerstitial cluster madel was invoked to explain the oxygenpressure dependeace of the electrical conductivity for $\mathrm{vO}_{2+x}$, and an oxygen vacancy rich model $\left(2 v_{0}^{a} o_{i} v_{0}^{b}\right)$ for $v_{4} O_{g-g}$. Allen et al 7 have recently shown that the $x$-ray photoelectron spectra of satellites of the ukf peaks can be related to a $2: 2: 2$ chain cluster in the oxygen sublattice (interstitial-rich complex). The linear ordering of oxygen clugters in hyperstoichiometric uranium dioxide has been discussed by Allen and Tempest, and a coordinative model for the defect structure of $\mathrm{JO}_{2+x}$. and $U_{4} \mathrm{O}_{9}$ has been ploposed by Allen et 21.9 A current sumary of the work on the defect structure of $\mathrm{VO}_{2+\mathrm{x}}$ can be found in a review of Colmenares. ${ }^{3}$ Even thougt, the 2:2:2 cluster appears to be the most favored configuration of defects used to explain many experimental results, other configurations have aiso been suggested. 10

The existence of well defined axidation regines and unique defect siructures in uranium oxides was confirmed by Howell et al. Il by positran lifetime 
studies of oxidized uranium samples. Positron lifetimes of $2350 \mathrm{fs}$ were associated with a vacancy rich defect state and 11 fetimes of 2400 po with an Interstitial rich defect. Confirmstion of the existense of distinct defects, for the various oxidizing condtions defined in references 3 and 4 , was obtained by Colmenares et al.12 with electron paramagnetic resonance on the same type of samples used for positron annihilation spectroscopy (PAS). 11

We are reporting EPR results obtained with uranium powder samples fully oxidized in dry air, water vapor, and alr/water vapor mixtures. The results reported previnusly ${ }^{12}$ are confirmed and additional paramagnetic centers, associated with chemisorbed spscies, have been identified. The temperature depensence of the g-value for these centers from room temperature to $10 \mathrm{~K}$ is also reported.

\section{EXPERUMENTAI.}

Depleted uranium powder, consisting of spheres $2170 \mathrm{wm}$ in diamecer, was used for the EPR measurements. The cotal metallic impurities in uranium powder were $2900 \mathrm{ppm}$ by weight, and the main impurittes were magnesium and iron at a level of 2400 and $n 300 \mathrm{ppm}$, respectively. the natural oxide on the uranium powder was removed by treatment with a 50-50 vol \% solution of $\mathrm{WNO}_{3}+\mathrm{H}_{2} \mathrm{O}$. The clean powder was dried first with absolute ethanol and dry argon followed by overnight evacuation at room cempsrature. The powder temperature was then gradually increased to $100^{\circ} \mathrm{G}$ under vacuum $\left(210^{-9} \mathrm{~Pa}\right)$ over a period of $8 \mathrm{~h}$ to remove adsorbed water. Samples of this powder were oxidized in dry oxygen ( $<5 \mathrm{ppm} \mathrm{H}_{2} \mathrm{O}$ ), oxygen-free water vapor, and mixtures of air/water vapor.

Clean uranium powder samples were oxidized completely in a thermogravimetric nultispecimen "Elow system" ( $\mathrm{N}_{2}$ or air carrier gas) described in a separate publication. ${ }^{13}$ Table 1 gives the oxidation conditions for che EPR samples. The purity of the gases used in the experiments were: research 
grade oxygen ( 99.99 mole 7 ) selected to have $<5$ ppm $\mathrm{H}_{2} \mathrm{O}$; high purity nitrogen selected to have $<4$ ppm $\mathrm{O}_{2}$; air containing typically $1-2 \mathrm{ppm} \mathrm{H}_{2} \mathrm{O}$.

The EPR cell used in this work consisted of a high purity silica tube $(225 \mathrm{~cm}$ long) attached to a metal-gasketed stainless steel fitting by a graded-glass seal, which in turn was fitted to an all-metal valve. This arrangement pemitted the evacuation $\left(n 10^{-8} \mathrm{~Pa}\right)$ and outgassing of samples at temperatures up to $500^{\circ} \mathrm{C}$. Oxidized samples were transferred from the oxidation apparatus into the EPR cells in an argon-filled glove box ( 10 $\mathrm{Ppm} \mathrm{H}_{2} \mathrm{O}$ and $\mathrm{O}_{2}$ ). Thus, adsorbed and chemisorbed species from a given gageous environment were preserved on the uranium oxide powder in the EPR cell ("as received" condition).

Magnetic resonance experiments were performed using a homodyne spectrometer operating in the $x$-band ( $69.5 \mathrm{gHz}$ ) at ambient and low temperatures. These could be set $\pm 0.2 \mathrm{~K}$ over the Lemperature range $10-300 \mathrm{~K}$.

The lattice pazameter of the oxides produced was determined by powder $x$-ray diffraction techniques. The EPR spectra of these uxides were decermined over a wide temperature range.

\section{RESULTS AND DISCUSSION}

The EPR spectrum of each oxide contained a subsiantial $\varepsilon=2$ component, as expected. The spectrum of the sample grown with $13.3 \mathrm{kPa} \mathrm{H}_{2} \mathrm{O}(\mathrm{v})$ in $\mathrm{N}_{2}$ is shown in fig. 1. The relative intensity of this $g=2$ resonance determined at $10 \mathrm{~K}$ is show plotted as a function of the lattice parameter ao in Fig. 2. As can be seen, the relation between the wwo shows that the $g=2$ line is related to the hyperstoichiowetry of the system, i.e., either to the amount of $\mathrm{U}_{4} \mathrm{O}_{9}$ present and/or the concentration of the defects present in the $\mathrm{UO}_{2}$ and/ar $\mathrm{U}_{4} \mathrm{Og}$.

That the resonance arises from a possible ferrimagnetic phase associated with $\mathrm{U}_{4} \mathrm{Og}_{9}$ may be ruled out on several grounds. First, the line position and widh of ferrimagnetic resonance are dependent on the anisotropy constants 
$K$ and the external geometrical shape through the demagnetising factors. For random shaped particles, a reasonable assumption here, both effects will contribute to the line width and position: Usually, for ferrimagnetic resonance, sigaificant shifts from $8=2$ occur with line widths of several hundred oersted. In this case, the position of the line in question, $8=2$, and its relatively narrow line width of 10 oersted is not in accord with ferrimagnetic resonance. Second, any ferrimagnetic resonance will show wild shifts in g-value as the Néel temperacure is approached from below, with accompanying severe line broadening. Above the Néel temperature, the ferrimagnetic resonance disappears. The $g=2$ resonance here displays none of these features. Third, ferrimagnetic resonance is only weakly dependent on temperature. In our case, the line observed shows decreasing incensity with temperature froll $\mathrm{OOK}$ to $300 \mathrm{~K}$; i.e., paramagnetic behavior. It is also unlikely that any Néel temperature associated with $U_{4} O_{9}$ is above $300 \mathrm{~K}$. Magnetic transitions in the urania system are observed at $30 \mathrm{~K}$ in $\mathrm{UO}_{2}, 5.9 \mathrm{~K}$ in $\mathrm{UO}_{2} .1$, $\mathrm{U}_{4} \mathrm{O}_{9}$ and $\mathrm{U}_{3} \mathrm{O}_{7} \cdot 14,15$

Intensity relations over a limited range such as shown in Fig. 2 cannot be used to determine in which phase the defect center is present. If present in $\mathrm{VO}_{2+x}$, the incensity will pass through the hyperstoichiometric range as the volume fraction of $\mathrm{UO}_{2+\mathrm{x}}$ decreases but the non-stoichlonetry increases. The same is true for $\mathrm{U}_{4} \mathrm{O}_{9}-\mathrm{y}$ as we cross the hyper-stoichiometric range in the opposite direction.

Further, very careful quantitative studies of the oxygen pressure dependence of the defect concentration may indicate in which phase the defect centers are located. The independence of the resonance line width of the paramagnetic defict over the range of stoichiometry studied suggest that the defect concentratjon is "dilute", and therefore contained in non-stoichiometric $\mathrm{UO}_{2+\mathrm{x}}$. An analysis of the site symetries in the two phases may also be useful in identifying the origin. At present, a paramagnetic $2: 2: 2$ defect in $v 0_{2+x}$ 
seems reasonable.

Depending upon the oxidizing conditfons, the EPR spectrum of the urania is also characterized by a number of other broad resonances several hundred oersted wide with $g$ values between 2.0 and 3.6. A particularly rich spectrum is shown in Fig. 3. These broad resonances could also be introduced by exposing the urania oxidizsd in dry air to $\mathrm{H}_{2} \mathrm{O}(\mathrm{v})$, and also to $\mathrm{H}_{2} \mathrm{O}(\mathrm{v})+\mathrm{O}_{2}$, at room temperature. We describe below our efforts to identify the magnetic species responsible.

Fig, 4a shows the EPR spectrum of specimen oxidized in pure air. Fig. $4 \mathrm{~b}$ shows the EPR spectrum after the specimen was exposed to $4.3 \mathrm{KPa} \mathrm{H}_{2} \mathrm{O}(\mathrm{v})$ at room temperature, and Fig. 4c that of a similar sample exposed, also at room cemperature, to $101 \mathrm{KPa} \mathrm{O}_{2}$ and $4.3 \mathrm{KPa} \mathrm{H}_{2} \mathrm{O}(\mathrm{v})$ simultaneously. The very broad resonance with an average $g,\langle g\rangle$, of 22.6 appears after exposure to $\mathrm{H}_{2} \mathrm{O}(\mathrm{y})$ and to $\mathrm{O}_{2}$ and $\mathrm{H}_{2} \mathrm{O}(\mathrm{v})$ simultaneously. The spectes responsible for this resonance can be almost completely removed by heating at $500^{\circ} \mathrm{C}$ under a pressure of $10^{-5} \mathrm{~Pa}$.

An attractive explanation of the above EPR daca is through reactions of the type $\mathrm{B}_{2} \mathrm{O}+\mathrm{O}^{2-}$ (lattice or interstitial)

$\neq \mathrm{OH}^{-}$(lattice or interstitial) $+\mathrm{OH}^{-}$(surface)

$2 \mathrm{OH}^{-}$(surface) $\rightleftarrows \mathrm{H}_{2} \mathrm{O}+2 \mathrm{C}^{-}$

We suggest at this time that the broad $\langle g\rangle=2.6$ resonances shown in Figs. $4 \mathrm{~b}$ and $4 \mathrm{c}$ are the $\mathrm{O}^{-}$species present on the surface of the urania. To some extent this suggestion is based on our work on alumina and the similarities of the observed behavior of this material when plasma sprayed inco water. (Plasma spraying is a process in which small particles are exposed to a very high temperature $\sim 10^{6} \mathrm{C}$ plasma for a very short time, $\sim 10^{-5}$ sec, before being ejected at supersonic velocities onto a substrate or as, in this case, tnto water. The small particles melt, but do not vaporize completely, so that metastable phases and novel chemistry may be realizeo). 
First, let u consider the $\mathrm{JO}_{2}$ exposed to an $\mathrm{O}_{2}-\mathrm{H}_{2} \mathrm{O}$ atmosphere. The 'g) value if the resonance in Fig. 4 is a marked function of temperature, where the resonace field is observed to decrease with decreasing temperature. The temperature variation of 8 determined from such measurements is shown in Fig. 5. As far as we are aware, this resonance has not been previously observed.

Let us now consider the EPR of alumina particles that have been plasma sprayed into water. A representative EPR spectrum of alumina particles prepared this way is shown in Fig. 6, while the temperature dependence of the $g$ value is shown in Fig. 7. The $g$ value observed in urania, as well as the temperature dependence is very similar to that observed for alumina powder which has been plasma sprayed into water.

The similarity between the $\langle g\rangle=2.6$ resonance of the urania exposed to water and oxggen is so similar to that of alumina exposed (at very high temperature) to water and oxygen that we suggest tiney are in fact of the same origin, namely an exchange coupled magnetic system of 0 - moments on the surface. (In the case of the alumina, $\mathrm{A} 1^{+2}$ or $\mathrm{A} 1^{+4}$ ions are unlikely, and bulk oxygen vacancies would not show a temperature dependent g-value; moreover the value of $g$ would be close to 2.00 ).

For a strongly coupled system, the resonance condirion cas be written as (Morrish 16 ):

$$
\omega^{2}=\gamma^{2} \mathrm{H}(\mathrm{H}+\mathrm{RM})
$$

where $w$ is the angular velocity $(\omega=2 \pi f$, being the frequency), $Y$ is the gyromagnetic ratio, $B$ is the magnetic field, $M$ is the magnetisation per unit area and $I$ is a "catch all" parameter involving demagnetising fields and anisotropy constants. For small $\mathrm{K}$, this equation reduces to:

$$
\mathrm{H}_{\text {res }}=\frac{\omega}{\gamma}-\frac{\mathrm{RM}}{2}\left[I-\frac{\mathrm{R} Y \mathrm{Y}}{4 \omega}\right]
$$


where $\mathrm{H}_{\mathrm{I}} \mathrm{s}$ is the applied field at which resonance condition (1) is satisfied. Casting this equation isto the form:

hv $=30 \mathrm{bs}^{\mathrm{BH}} \mathrm{res}$

where gobs is the splitting factor, $g_{0 b s}$ can be calculated from (2) and

(3) as

gobs $=8\left[1+\frac{R Y Y}{2 \omega}\left(1-\frac{R T Y}{4 \omega}\right)\right)$

where $g$ is the free electron splitting factor with a value of 2.00 .

This expression shows that, in this case the observed $g$ values are greater than 2.0; alternatively that the resonance occurs at lower magnetic fields compared to those required for spin-only resonance. Interpreted this way, the increase in the splitting factor, gobs, with decreasing temperature below about $70 \mathrm{R}$ comes about from the supposed increase in the resultant magnetization that octurs with decreasing temperature. Moreover, the inferred cemperature dependence of $M(T)$ below the Néel temperature is in qualitative agreement with that expected from a magnetically ordered system, e.g., a simple ferrice. Above $80 \mathrm{~K}$, i.e., above the supposed Nétl remperacure, a severely dipole-dipole broadened EPR line is expected vith the splitting factor equal to the average of the consticuent magnetic species. For urania, the $g$ value of the resorance is about 2.3 at the highest cemperature that it can be observed, 80K. For plasma sprayed alumina, the high temperature g-values are indicated by arrows, namely $=2.25$. Similar g-values have been observed for $\mathrm{O}_{2}^{-}$and $\mathrm{O}^{-}$adsorbed on oxide surfaces, Lunsford 17 .

\section{CONCLUSION}

EPR has revealed a well defined paramagnetic defect center in hyperstoichiometric $\mathrm{UO}_{2+\mathrm{x}} / \mathrm{U}_{4} \mathrm{O}_{9-\mathrm{y}}$. It is found that the number of these defects increase with $x$ and the evidence favors a center associated with the 2:2:2 defect of Willis.

The surface of $\mathrm{DO}_{2}$ bas been shown to be highly reactive with water. The most likely reaction is the hydrolysis of water to form $0^{-}$( $\mathrm{or}_{2}{ }^{-}$) chemisorbed on the surface and $\mathrm{H}_{2}$. The magnetic resonance data can be explained on 
this basis only by assuming a strong coupling between chese ions. This implies that the density on the surface of the paramagnetic species is very large with almost complete coverage.

Further work is in progress to characterize and understand this system more completely.

\section{ACKNOWLEDGMENTS}

We would like to acknowledge the assistance of $T$. McCresry (ILL) and H. Herman (SUNY at stonybrook) for providing the plasma sprayed alumina. This work was performed with support frow the U.S. Dept. of Energy by LL under Contract No. W-7405-ENG-48.

\section{REFERENCES}

1. C.A. Colmenares, "The Oxidation of thorium, Uranium and Plutonium", in progress in Solid State Chemistry, Vol. 9, 139-239, J.0. MacCaldin and G. Somorjai, eds., Pergamon Press (1975).

2. A.G. Ritchie, J. Nec1. Mater. 102, 170 (1981).

3. C.A. Colmenares, "Oxidation Mechanisms and Catalytic Properties of the Actinides", in progress in Solid State Chemistry, in press (1985).

4. C.A. Colmenares, R. Howell and T. McCreary, "Oxidation and Hydriaing of Uranium St:died by Pasitron Antihilation", Lawresce Livermore Natianal Laboratory report VCRL-88549, April 1981.

5. B.T.M. Willis, Acta Cryst, A-34, 88 (1978).

6. T. Matsui and K. Naito, J. Nucl, Sci. Tech. 12, 250 (1975).

7. G.C. Allen, P.M. Tucker, and J.W. Tyler, Vacuur 32, 481 (1982),

8. G.C. Allen and P.A. Tempest, J. Chem. Soc. Dalton Trans. 2169 (1982).

9. G.C. Allen, P.A. Tempest, and J. Tyler, Nature 295, 48 (1982).

10. C.R.A. Caclow, J. Phys. C: Solid State Phys. 9, 1859 (1976).

11. R.H. Howe 11, C. Colmenares, and T. McCreary, J. Less-Common Met. 98 , 267 (1983).

12. C.A. Colmenares, R. Howell, R.K. MacCrone, and S.R. Shatynski, Proceedings of 9th International Congress on Metallic Corrosion, June 3-7, Toronto, Canada, 1983 Vol. 4, P. 44 (1984) published by the National Research Council of Canada.

13. C.A. Colmenares, D.R. McKenzie, and T.E. Schell, J. Phys. E. 6, 1121 (1973).

14. M.J.M. Leask, L.E.J. Roberts, A.J. Walter and W.P. Wolf, J. Chem. Soc., 4788 (1963). 
9.

15. A. Arrot and J.E. Goldman, Phys. Rev:, 108, 948 (1957).

16. A.H. Morrisb, Physical Principles of Magnet1sm, John Wiley Inc., New York, p. 607, 542 (1965).

17. J.H. Lunsford, Cacalysis Revieus, 8(1), 135 (1973). 
Table 1. Oxidation conditions for urantum powder

$\begin{array}{lll}\text { Oxidant } & \text { Temperature } & \text { Time to complete } \\ \text { (gas flow }=1 \mathrm{~J} / \mathrm{min} ; & { }^{\circ} \mathrm{C} & \text { oxidetion, } \mathrm{n} \\ \text { Total } \mathrm{P}=101 \mathrm{kPa} \text { ) } & & \end{array}$

$\begin{array}{lll}\text { Dry air } & 180 & 196 \\ 13.3 \mathrm{kPa} \mathrm{H} \mathrm{H}_{2} \mathrm{O}(\mathrm{v}) \text { in } \mathrm{N}_{2} & 100 & 170 \\ 13.3 \mathrm{kPa} \mathrm{H} \mathrm{H}_{2} \mathrm{O}(\mathrm{v}) \text { in air } & 100 & 742\end{array}$




\section{Figure Captions}

Fig. 1 EPR spectrum at $10 R$ showing $g=2$ resonance for the urania produced by oxidizing uranium in $13.3 \mathrm{kPa} \mathrm{H}_{2} \mathrm{O}(\mathrm{v})$ at $100^{\circ} \mathrm{C}$.

Fig. 2 Dependence of $g=2$ resonance intensity on lattice parameter of the urania.

Fig. 3 EPR spectrum at 40K of urania obtained by oxidizing uranium with $13.3 \mathrm{KPa} \mathrm{H}_{2} \mathrm{O}(\mathrm{v})$ in air at $100^{\circ} \mathrm{C}$.

Fig. 4 EPR spectrul of sample produced by oxidation in dry air.

(a) as oxidized

(b) exposed to $4.3 \mathrm{kPa} \mathrm{H} O(\mathrm{~V})$ at room temperature

(c) exposed to $4.3 \mathrm{kPa} \mathrm{H}_{2} \mathrm{O}(\mathrm{v})+101 \mathrm{kPa} \mathrm{O}_{2}$ at roon temperature.

Fig. 5 Temperature dependence of the g-value of resonance shown in Fig. 4.

Fig. 6 EPR spectrum of plasma sprayed alumina at 60X.

Fig. 7 Temperature dependence of the g-value of resnnance shum in Fig. 6, (top) as sprayed (bottou) treated with dimethylanthracene (DMAN).

Work performed under the auspices of the U.S. Department of Energy by the Lawrence Livermore National Laboratory under contract No. W-7405-ENG-48. 


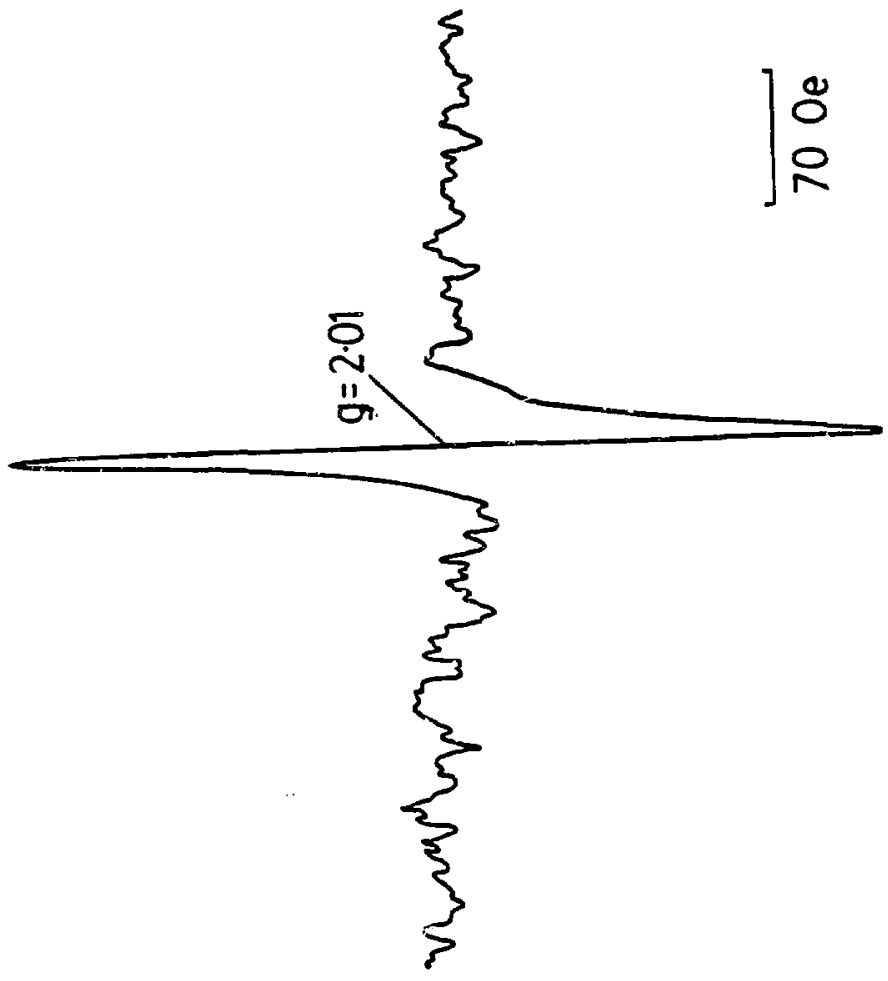

Fig. 1 


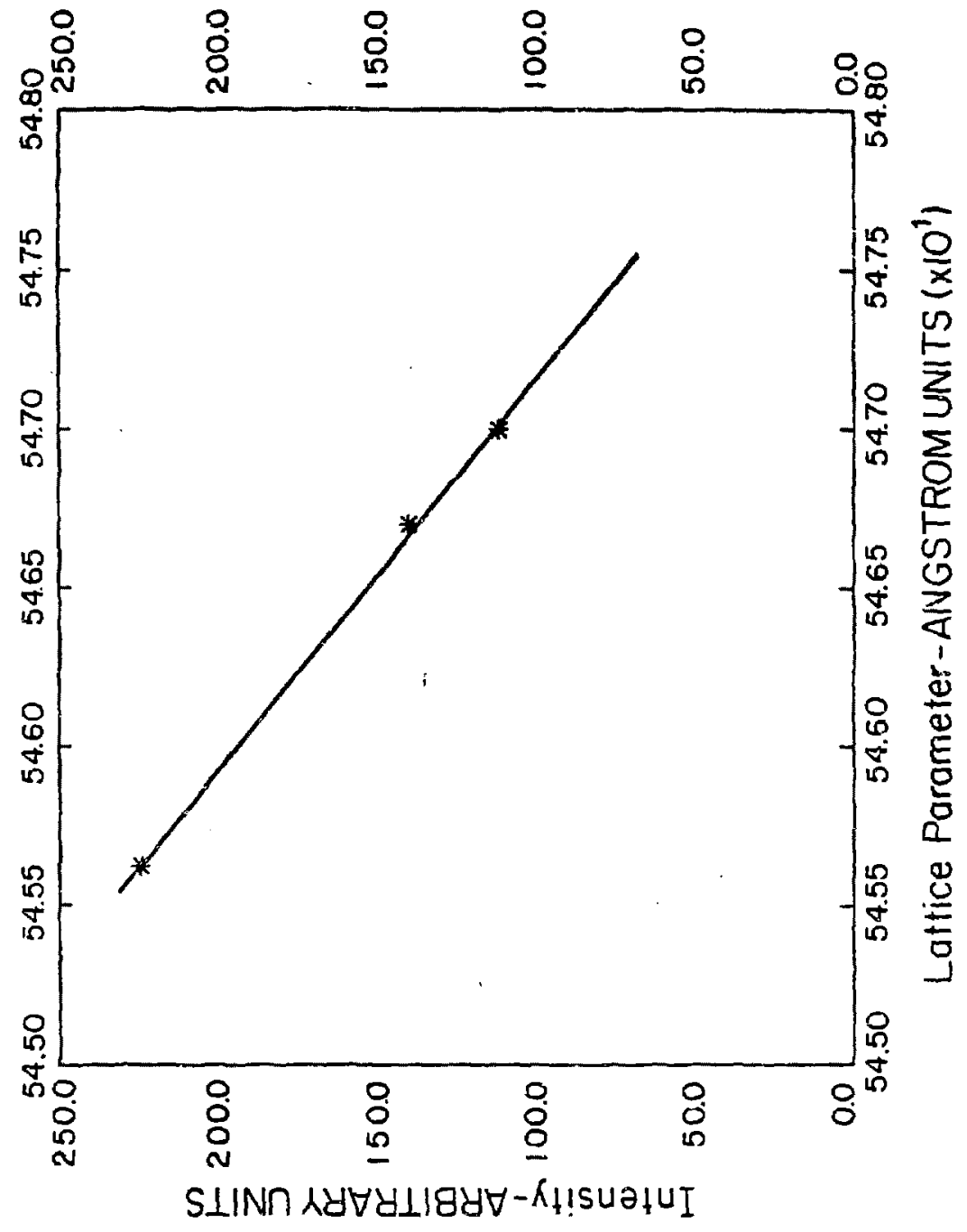

Fig. 2 


$$
\xi
$$




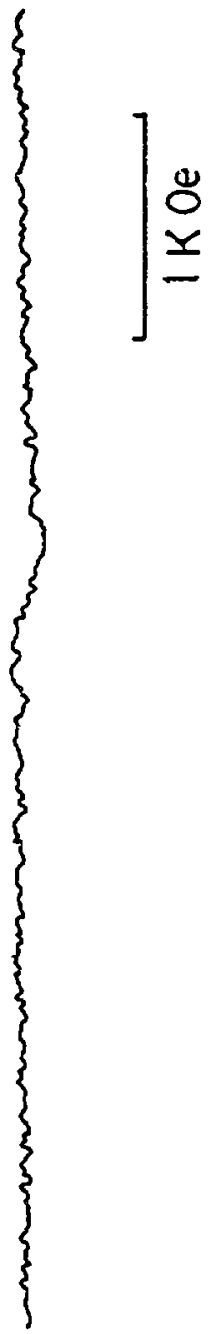

Fig. 4a 


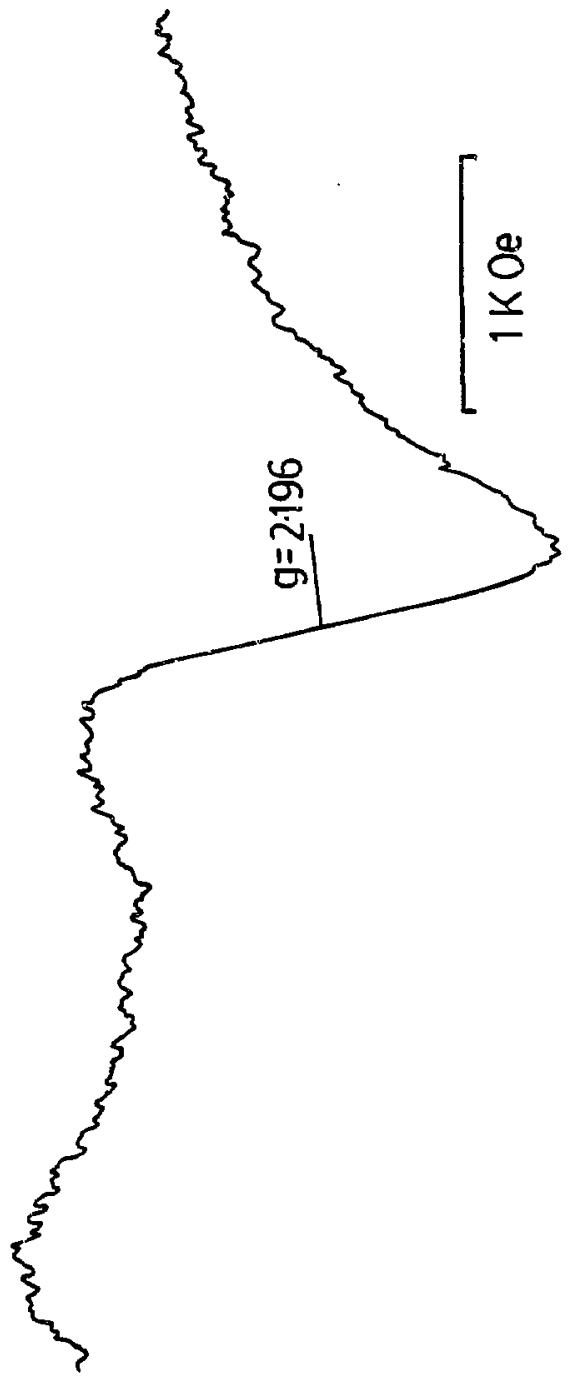

Fig. 4b 


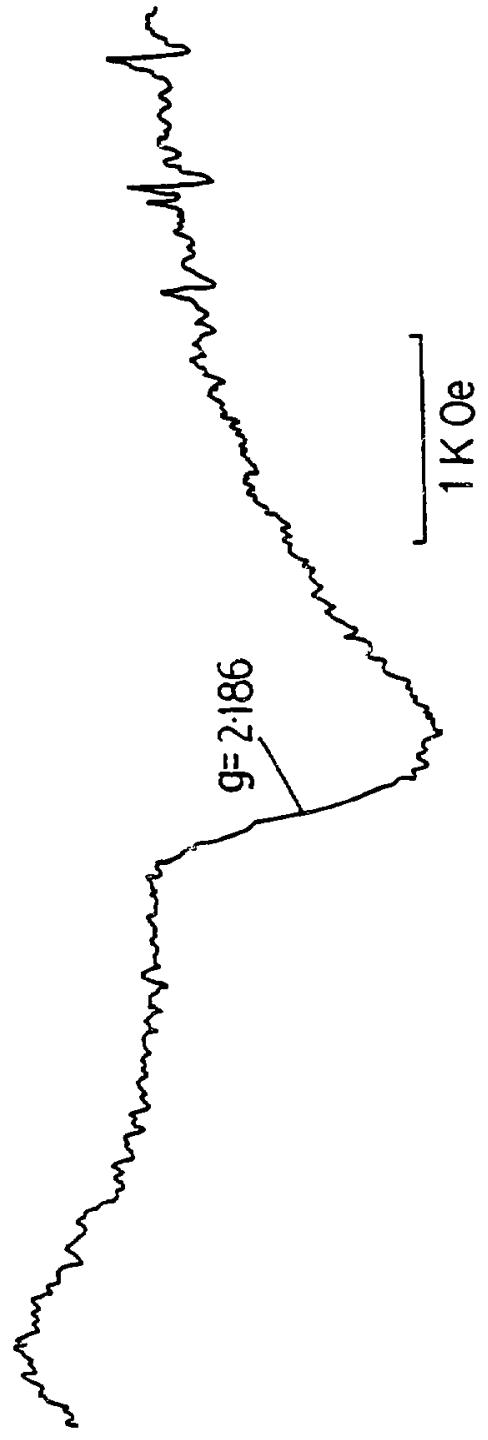

Fig. $4 \mathrm{C}$ 


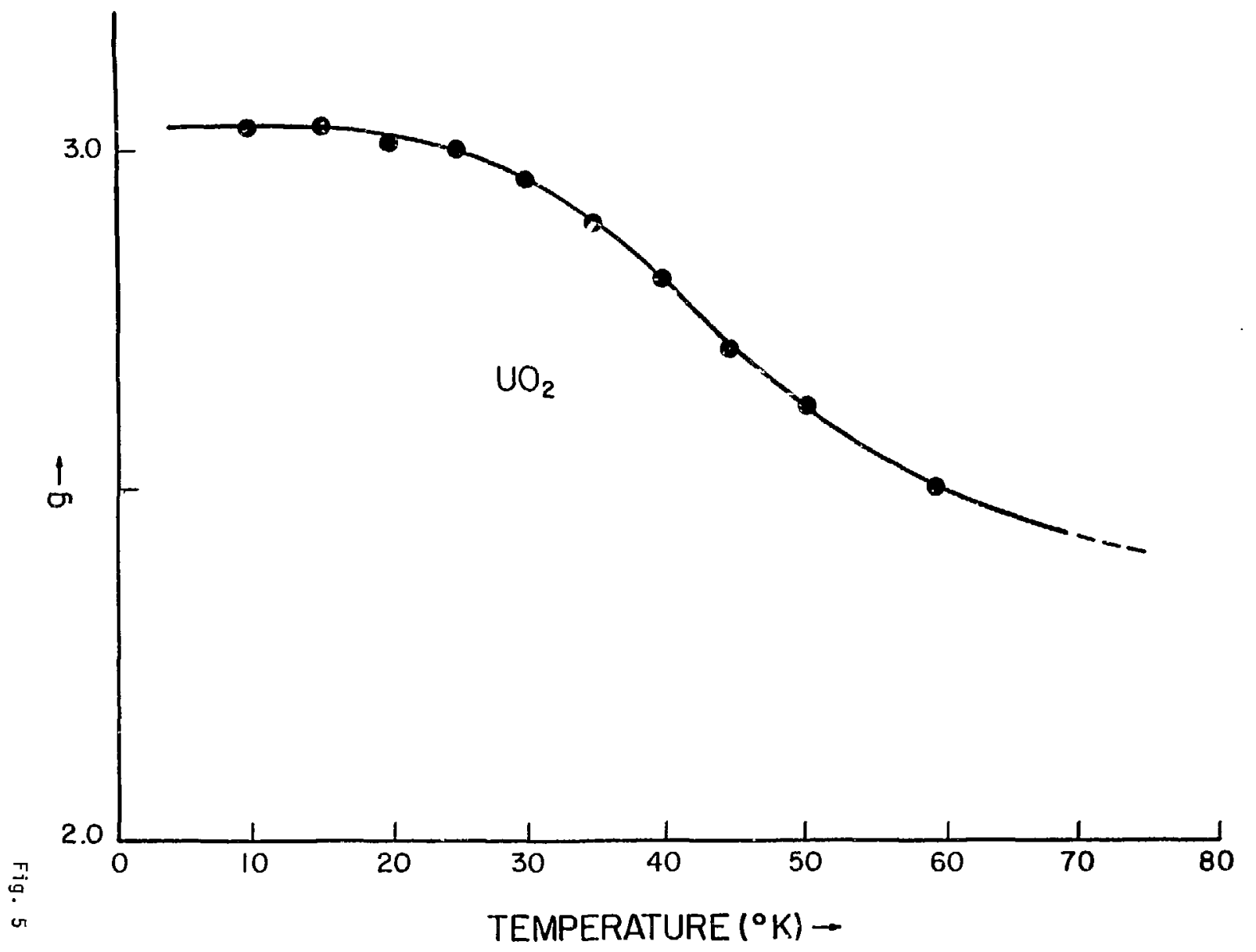




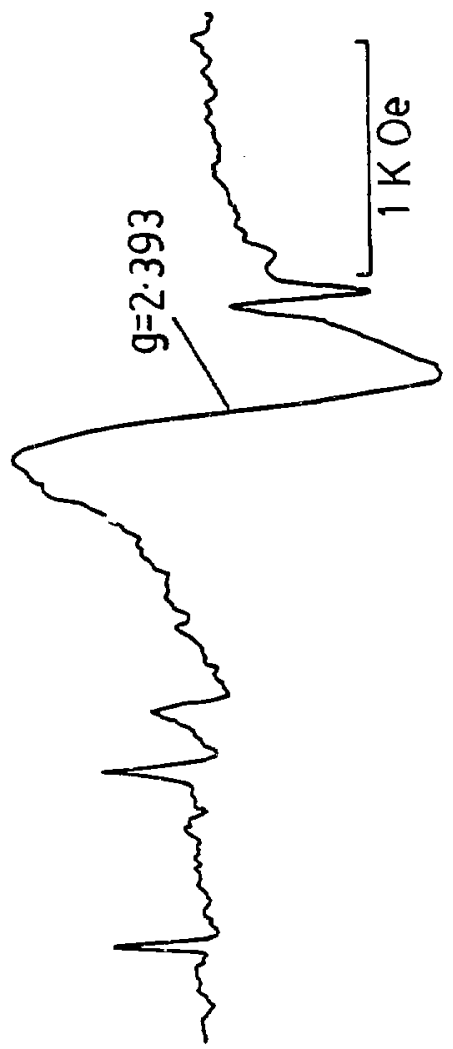

Fig. 6 


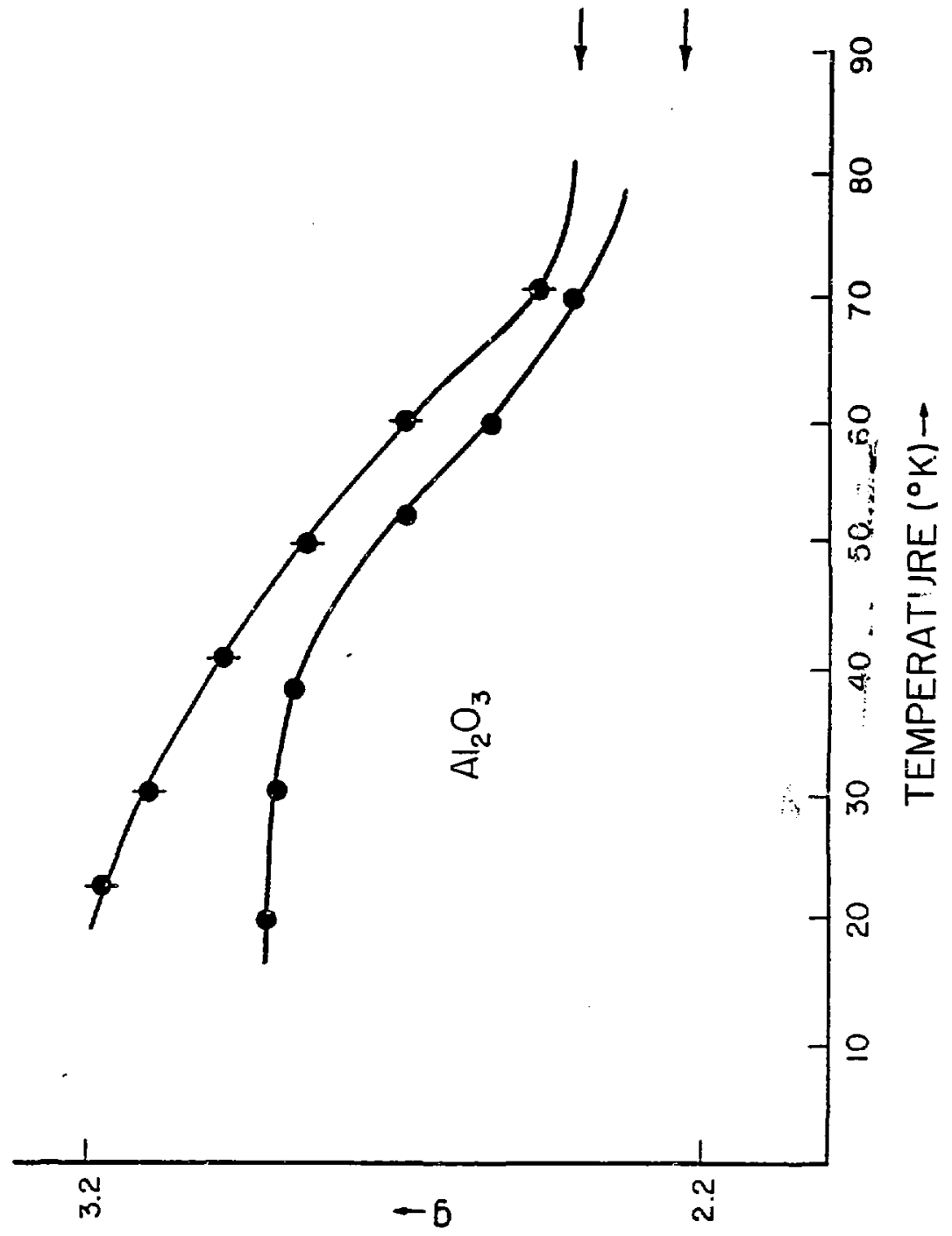

Fig. 7 